\title{
37. STABLE-ISOTOPE EVIDENCE FOR THE ORIGIN OF SECONDARY CARBONATE VEINS IN DEEP SEA DRILLING PROJECT LEG 58 BASALTS
}

\author{
Thomas F. Anderson, Department of Geology, University of Illinois at Urbana-Champaign
}

\section{INTRODUCTION}

The stable-isotope composition of carbonate minerals is a function of the temperature and isotopic composition of the materials from which they were precipitated or recrystallized. Because carbonates are among the most abundant secondary phases in oceanic volcanic rocks, information derived from their isotopic composition is useful in determining the environment(s) of seafloor alteration. Isotopic analyses of secondary carbonates in basalt recovered from numerous DSDP sites have been reported previously (Anderson and Lawrence, 1976; Brenneke, 1977; Lawrence et al., 1977; Seyfried et al., 1976; among others). These results are consistent with the formation of most secondary carbonates with sea water at low temperatures. The good recovery of basalts during DSDP Leg 58 provided the opportunity to extend the isotopic study of low-temperature alteration and vein formation to the crust of marginal ocean basins. The evidence for complex off-ridge volcanism and intrusive emplacement encountered at Leg 58 sites (Klein et al., 1978) suggested that modes of alteration at these sites might differ from those previously observed and described.

We have isotopically analyzed carbonates in veins from 17 samples of volcanic rocks from Leg 58. These samples are representative of most of the common types of volcanic rocks encountered in Leg 58 (sills, subsediment flows, pillow lavas, etc.). Thin sections of each sample were examined and described to determine the extent to which petrographic characteristics of the vein material and adjacent host rock are correlated to the isotopic data. Oxygen-isotope analyses of several quartz and smectite samples from the veins were provided by R. Houghton.

\section{GEOLOGIC SETTING OF THE SAMPLES}

Detailed description of the petrology, chemistry, and apparent mode of emplacement of the volcanic rocks on Leg 58 are found in the site reports (this volume), and Dick et al. (this volume). The volcanic rocks recovered at the sites where basement was penetrated are dominated by massive basalt and diabase sills and subsediment flows. Pillow lavas were encountered in the section at Sites 442 and 443 , but not at Sites 444 and 446 . The basalts at Sites 443 and 444 are olivine tholeiites comparable to normal oceanic basalts in composition, structure, and vesicularity. The basalts at Site $\mathbf{4 4 2}$ differ from normal oceanic basalts by the lack of olivine, presence of early crystallized pyroxene, and unusually high vesicularity (proba- bly indicating a high initial volatile content). The basalts and diabases of some of the massive sills at Site 446 are highly alkalic, contain 8 to 20 per cent basaltic hornblende, and are rich in $\mathrm{Fe}$ and $\mathrm{Ti}$.

The extent of weathering and alteration of the basalts is variable among the sites and at a given site. For example, petrographic evidence suggests that the extent of alteration at Site 443 increases with depth, and some phase of this alteration may have been the result of hydrothermal activity (Site 443 report, this volume). Filled-fracture veins are common to abundant at all sites. Some of the veins can be traced vertically for more than $50 \mathrm{~cm}$. Calcite is the dominant secondary vein mineral in the basalts at Sites 442, 443, and 444 (Shikoku Basin), whereas clay minerals are dominant in the veins at Site 446 (Daito Basin).

\section{TECHNIQUES}

Whole-rock samples of the major volcanic units containing carbonate veins were selected from an extensive collection of Leg 58 material made available to us by Co-Chief Scientist G. deV. Klein. Stratigraphic information on the samples is given in Table 1. The wholerock samples were cut approximately perpendicular to each vein. A thin section was prepared from one of the slabs, and the vein material was sampled from the other slab, using a dental drill. (Material from two veins was sampled from 446A-13-1, 80-84 cm.) No particular care was taken to hand pick carbonate from the resulting sample. The material was dried in an oven at $50^{\circ} \mathrm{C}$ and crushed finely with an agate mortar and pestle. Carbon dioxide was liberated from the samples by reaction with 100 per cent $\mathrm{H}_{3} \mathrm{PO}_{4}$ at $25^{\circ} \mathrm{C}$ (McCrea, 1950) and analyzed by mass spectrometry. Isotopic compositions are reported in the conventional $\delta$-terminology, as per mill deviations from SMOW for oxygen and from PDB for carbon. The working standard in the mass spectrometer was calibrated to SMOW by repeated analyses of $\mathrm{CO}_{2}$ equilibrated with the International Water Standards (Gonfiantini, 1978). To calculate the oxygen-isotope composition of the solid carbonate, we applied the $\mathrm{CO}_{2}$ kinetic isotope-fractionation factor for pure calcite, $(=1.01025$; modified after Sharma and Clayton, 1965). The carbon-isotope composition of the standard gas was calibrated to PDB by repeated analyses of NBS-20 (Craig, 1957). The reproducibility of this analytical procedure, based on repeated analyses of secondary-carbonate standards, is less than \pm 0.1 per mill for both carbon and oxygen. 
TABLE 1

Stratigraphic Information on the Carbonate Veins

\begin{tabular}{|c|c|c|c|}
\hline $\begin{array}{l}\text { Sample } \\
\text { (interval in } \mathrm{cm} \text { ) }\end{array}$ & $\begin{array}{l}\text { Depth } \\
(\mathrm{m})\end{array}$ & Unit and Thickness & Location in Unit \\
\hline $442 \mathrm{~B}-6-2,134-137$ & $318^{\mathrm{a}}$ & I-G $(2 \mathrm{~m})$ & $100 \mathrm{~cm}$ below the upper chill boundary. \\
\hline $8-7,124-128$ & 343 & $\mathrm{I}-\mathrm{L}(1.5 \mathrm{~m})$ & $20 \mathrm{~cm}$ above the lower chill boundary. \\
\hline $9-3,80-84$ & 347 & $\mathrm{I}-\mathrm{O}(5 \mathrm{~m})$ & Near the center of the unit. \\
\hline $10-2,16-19$ & 335 & II (?) & $\begin{array}{l}150 \mathrm{~cm} \text { below the top of the pillow-lava sequence, which is apparently overlain by a } \\
\text { few meters of fossiliferous mud. }\end{array}$ \\
\hline $443-50-2,36-39$ & $465^{\mathrm{a}}$ & I-A $(16 \mathrm{~m})$ & Near the center of the unit. \\
\hline $53-2,87-89$ & 484 & $\mathrm{I}-\mathrm{C}(3 \mathrm{~m})$ & In the bottom third of the unit. \\
\hline $55-2,93-95$ & 503 & II-A $(4 \mathrm{~m})$ & In the basal zone of pillow-lava unit overlain by an intraformational limestone breccia. \\
\hline $56-4,24-27$ & 509 & II-B $(8 \mathrm{~m})$ & In the lower part of the unit; $6 \mathrm{~cm}$ of limestone and chalk are at the base. \\
\hline $58-3,77-90$ & 524 & II-D $(5 \mathrm{~m})$ & In the lower part of the unit. \\
\hline $59-1,95-98$ & 531 & II-F $(2 \mathrm{~m})$ & In the lower part of the unit; $12 \mathrm{~cm}$ of nannofossil chalk and limestone are at the base. \\
\hline $59-5,84-88$ & 535 & II-H $(2 \mathrm{~m})$ & Immediately above the basal chill zone. \\
\hline $61-3,119-124$ & 552 & $\begin{array}{l}\text { IV-B }(1 \mathrm{~m}) / \\
\text { IV-C }(9 \mathrm{~m})\end{array}$ & In the chill margin between the two units. \\
\hline $63-3,25-30$ & 571 & IV-E $(11 \mathrm{~m})$ & In the upper part of the unit. \\
\hline $444 \mathrm{~A}-20-2,131-133$ & 246 & $\mathrm{I}(12 \mathrm{~m})$ & In the upper part of the sill; $21 \mathrm{~m}$ of mudstone underlies the sill. \\
\hline $27-5,17-19$ & 306 & II $(?)$ & $34 \mathrm{~m}$ below the top of the unit, $1 \mathrm{~m}$ above the base of the hole. \\
\hline $446 \mathrm{~A}-4-1,66-72$ & 401 & II-A $(16 \mathrm{~m})$ & $5 \mathrm{~m}$ below the top of the sill. \\
\hline $13-1,80-84$ & 477 & $\mathrm{~V}-\mathrm{A}(4 \mathrm{~m})$ & Near the lower chill margin. \\
\hline
\end{tabular}

avolcanic sequence begins at sub-bottom depths of $290 \mathrm{~m}$ in Hole $442 \mathrm{~B}$ and $457 \mathrm{~m}$ in Hole 443 .

\section{PETROGRAPHIC CHARACTERISTICS}

Petrographic characteristics of veins analyzed in this study are described in Table 2 . Calcite is the most abundant mineral in the veins. The predominant texture of the calcite is coarse-grained, equant spar, with irregular to interlocking grain boundaries. This variety fills the central portion of most veins and presumably represents the latest episode of mineralization. Polycrystalline calcite with a radial hemispheric texture and wavy extinction also occurs in the central portion of some veins. Finer-grained, fibrous calcite oriented normal to the vein walls and often showing dog-tooth terminations is common at the margin of veins. The finer-grained calcite is typically iron-stained and contains inclusions of clays and other alteration products, whereas the coarser-grained varieties are typically clear and relatively free of inclusions. No biogenic carbonate was noted in any of the veins.

Clay minerals (mostly smectite) were common to abundant in most of the veins. They are distributed randomly in the veins, but are most common along fracture walls. The clays were often stained reddish-brown, particularly where the wall of the host rock has been oxidized. A coarse, fibrous smectite with a radial hemispheric texture was abundant in Sample 446A-4-1, $66-72 \mathrm{~cm}$. Fibrous celadonite was present as a lining of the fracture walls in a few of the veins. An unusual, brown-yellow, strongly pleochroic, fibrous mineral, tentatively identified as mica, was observed in Sample 444A-27-5, 17-19 cm.

Zeolites are common in the central portions of the veins with coarse calcite and as radiating prismatic crystals lining fracture walls.

Reddish-brown Fe-oxides and iron-stained alteration products are widely distributed in veins, both as concen- trations of inclusions in the secondary minerals and as coatings and stains along fracture walls. The extent of oxidative alteration of the host rock adjacent to the veins is quite variable, ranging from non-existent to many times the width of the vein and increasing toward the vein.

\section{ISOTOPIC DATA}

The isotopic composition of the vein carbonates are listed in Table 2 and plotted in Figure 1. Two distinct groups of veins can be recognized on the basis of oxygen-isotope variations

All the veins from Holes 442B, 443, and 444A have $\delta^{18} \mathrm{O}$ values in the range 32.8 to 34.4 per mill. The veins from Hole $442 \mathrm{~B}$ have higher $\delta^{18} \mathrm{O}$ values than the veins from Hole 443; the two veins from Hole 444A cover the total range. Based on the oxygen-isotope-fractionation data of O'Neil et al. (1969) for calcite-water equilibrium, these veins are in equilibrium with modern deep ocean water (Craig and Gordon, 1965) at 3 to $8^{\circ} \mathrm{C}$. If the hypothetical oxygen-isotope composition of Tertiary ocean water is corrected for the absence of polar ice caps (Shackleton, 1967), then the isotopic temperatures are $4^{\circ} \mathrm{C}$ lower.

Most of the veins in this group have $\delta^{13} \mathrm{C}$ values in the range +1.3 to +2.8 per mill. These values are consistent with carbon-isotope equilibrium at low temperatures between carbonate and dissolved inorganic carbon in the deep sea (Emrich et al., 1970; Kroopnick, 1974). Three of the samples have $\delta^{13} \mathrm{C}$ values of -1.0 to -0.3 per mill, suggesting minor contributions from ${ }^{13} \mathrm{C}$-depleted carbon reservoirs such as oxidized organic carbon.

The other group of veins based on oxygen-isotope variations includes the three samples from Hole 446A. These veins have $\delta^{18} \mathrm{O}$ values of 24.9 to 25.6 per mill and 
TABLE 2

Isotopic Composition and Petrographic Characteristics of the Carbonate Veins

\begin{tabular}{|c|c|c|c|}
\hline $\begin{array}{l}\text { Sample } \\
\text { (interval in } \mathrm{cm} \text { ) }\end{array}$ & $\begin{array}{l}{ }^{13} \mathrm{C}(\mathrm{PDB}) \\
(\% \mathrm{\%})\end{array}$ & $\begin{array}{l}\delta^{18} \mathrm{O}(\mathrm{SMOW}) \\
(\%)\end{array}$ & Petrographic Characteristics \\
\hline 442B-6-2, 134-137 & +1.8 & +34.3 & $\begin{array}{l}\text { Rim of microcrystalline, fibrous calcite containing Fe-oxide and clay inclusions; clear, } \\
\text { coarsely crystalline calcite in the center; the host rock is highly altered, particularly } \\
\text { near the vein. }\end{array}$ \\
\hline $442 \mathrm{~B}-8-7,124-128$ & +1.7 & 33.8 & $\begin{array}{l}\text { Equant, sparry calcite with patches of Fe-oxides and clay; the host rock is highly } \\
\text { altered. }\end{array}$ \\
\hline $442 \mathrm{~B}-9-3,80-84$ & +2.3 & 33.5 & $\begin{array}{l}\text { Rim of clay, Fe-oxide, and finely crystalline calcite; clear, coarsely crystalline, dog- } \\
\text { tooth spar fills the center part; alteration of the host rock appears to increase toward } \\
\text { the vein. }\end{array}$ \\
\hline $442 \mathrm{~B}-10-2,16-19$ & +1.9 & 33.8 & $\begin{array}{l}\text { Clear, equant spar in a host rock of volcanic glass partially altered to palagonite, clays, } \\
\text { and zeolites. }\end{array}$ \\
\hline $443-50-2,36-39$ & -0.3 & 33.4 & $\begin{array}{l}\text { Coarsely crystalline, clear calcite rims the vein wall; finely crystalline calcite with } \\
\text { inclusions of Fe-oxides and clay occurs in the central part; alteration of the host rock } \\
\text { increases toward the vein. }\end{array}$ \\
\hline $443-53-2,87-89$ & +2.3 & 32.8 & $\begin{array}{l}\text { Medium-crystalline calcite with a high concentration of alteration products and host- } \\
\text { rock remnants; irregular boundaries. }\end{array}$ \\
\hline $443-55-2,93-95$ & +2.1 & 33.2 & $\begin{array}{l}\text { Very coarsely crystalline calcite with wavy extinction and occasional patches of gray- } \\
\text { green clay; finely crystalline, dog-tooth calcite lines the vein walls in places; host rock } \\
\text { is highly altered. }\end{array}$ \\
\hline $443-56-4,24-27$ & +2.4 & 33.0 & $\begin{array}{l}\text { Clay, brown and clear zeolite(?) and finely crystalline dog-tooth calcite line the vein } \\
\text { walls; clear, equant, coarsely crystalline calcite surrounds central vugs. }\end{array}$ \\
\hline $443-58-3,77-90$ & -1.0 & 33.0 & $\begin{array}{l}\text { Fine, fibrous calcite lines irregular vein boundaries and is separated from clear, coarsely } \\
\text { crystalline calcite by a thin layer of clay and Fe-oxide; numerous inclusions of clay, } \\
\text { palagonite, Fe-oxides. }\end{array}$ \\
\hline $443-59-1,95-98$ & +1.9 & 33.4 & $\begin{array}{l}\text { Fibrous clay and zeolite line the vein walls, followed by a thin, very finely crystalline, } \\
\text { fibrous calcite; then a coarsely crystalline calcite in a fan-like habit; the central part is } \\
\text { empty; no observable increase in alteration in the host rock toward the vein. }\end{array}$ \\
\hline $443-59-5,84-88$ & +2.7 & 33.3 & $\begin{array}{l}\text { Microcrystalline calcite containing inclusions of Fe-oxides and clays with patches of } \\
\text { coarsely crystalline calcite in a "vein" connecting two vesicles. }\end{array}$ \\
\hline $443-61-3,119-124$ & +2.8 & 33.0 & $\begin{array}{l}\text { Fe-oxide and celadonite line the vein walls, followed in places by a fibrous, drusy } \\
\text { calcite; where druse is absent, the calcite is coarsely crystalline and contains altered } \\
\text { fragments of plagioclase. }\end{array}$ \\
\hline $443-63-3,25-30$ & +2.6 & 33.1 & $\begin{array}{l}\text { Several generations of calcite, including finely crystalline calcite associated with Fe- } \\
\text { oxides and clays along the vein boundaries and two distinct generations of coarsely } \\
\text { crystalline, clear calcite with a fan-like habit. }\end{array}$ \\
\hline $444 \mathrm{~A}-20-2,131-133$ & -0.8 & 33.0 & (Carbonate vein removed from thin section during preparation.) \\
\hline $444 \mathrm{~A}-27-5,17-19$ & +1.3 & 34.4 & $\begin{array}{l}\text { Rim of fibrous calcite surrounding patches of clear, coarsely crystalline, equant spar; } \\
\text { high birefringence, red-brown mica (biotite?) abundant locally. }\end{array}$ \\
\hline $446 \mathrm{~A}-4-1,66-72$ & -0.1 & 25.6 & $\begin{array}{l}\text { Composite vein of finely crystalline and equant, coarsely crystalline calcite; coarsely } \\
\text { crystalline clay in a rosette-like habit; and equant, coarsely crystalline quartz; altera- } \\
\text { tion of the host rock increases toward the vein. }\end{array}$ \\
\hline $\begin{array}{l}446 \mathrm{~A}-13-1,80-84 \mathrm{~A} \\
446 \mathrm{~A}-13-1,80-84 \mathrm{~B}\end{array}$ & $\begin{array}{l}-2.2 \\
-2.7\end{array}$ & $\begin{array}{l}24.9 \\
25.4\end{array}$ & $\begin{array}{l}\text { Numerous generations of calcite, including three distinct layers of finely crystalline, } \\
\text { fibrous calcite; irregular, patchy calcite containing a high concentration of alteration } \\
\text { products; and a clear, equant spar of medium crystallinity. }\end{array}$ \\
\hline
\end{tabular}

$\delta^{13} \mathrm{C}$ values -2.7 to -0.1 per mill. The corresponding oxygen-isotope temperature for equilibrium with modern bottom water is 37 to $41^{\circ} \mathrm{C}$; alternatively, if the veins were deposited at $2^{\circ} \mathrm{C}$, then the $\delta^{18} \mathrm{O}$ of the water was -8 to -9 per mill (Table 3 ).

\section{INTERPRETATION}

\section{Holes 442B, 443, and 444A}

The oxygen-isotope compositions of the carbonate veins from these sites are consistent with equilibrium with sea water at sea-floor temperatures. There is no apparent correlation between the oxygen-isotope composition and petrographic characteristics of the vein or the location of the vein in the basalt unit. Since the low-temperature alteration of basalt by sea water in a closed system can lead to depletion of ${ }^{18} \mathrm{O}$ in the water (Lawrence et al., 1975, 1979), it is evident that the oceanic crust at these sites remained "open" to circulation of large volumes of sea water throughout the interval of carbonatevein deposition at these sites. Lawrence and co-workers have shown that the low-temperature alteration of sediments and basalts at several DSDP sites results in characteristic gradients in the concentrations of major cations and the oxygen-isotope composition in interstitial pore water (e.g., Lawrence et al., 1975, 1979). The absence of cation gradients in Holes 442B, 443, and 444A further substantiates that these low-temperature transformations have proceeded and continue to proceed under conditions of a large water/rock ratio.

The carbon-isotope composition of all but three of the veins from Holes 442B, 443, and 444 are consistent with equilibrium with carbonate in deep ocean water. The three exceptions are somewhat depleted in ${ }^{13} \mathrm{C}$ rela- 


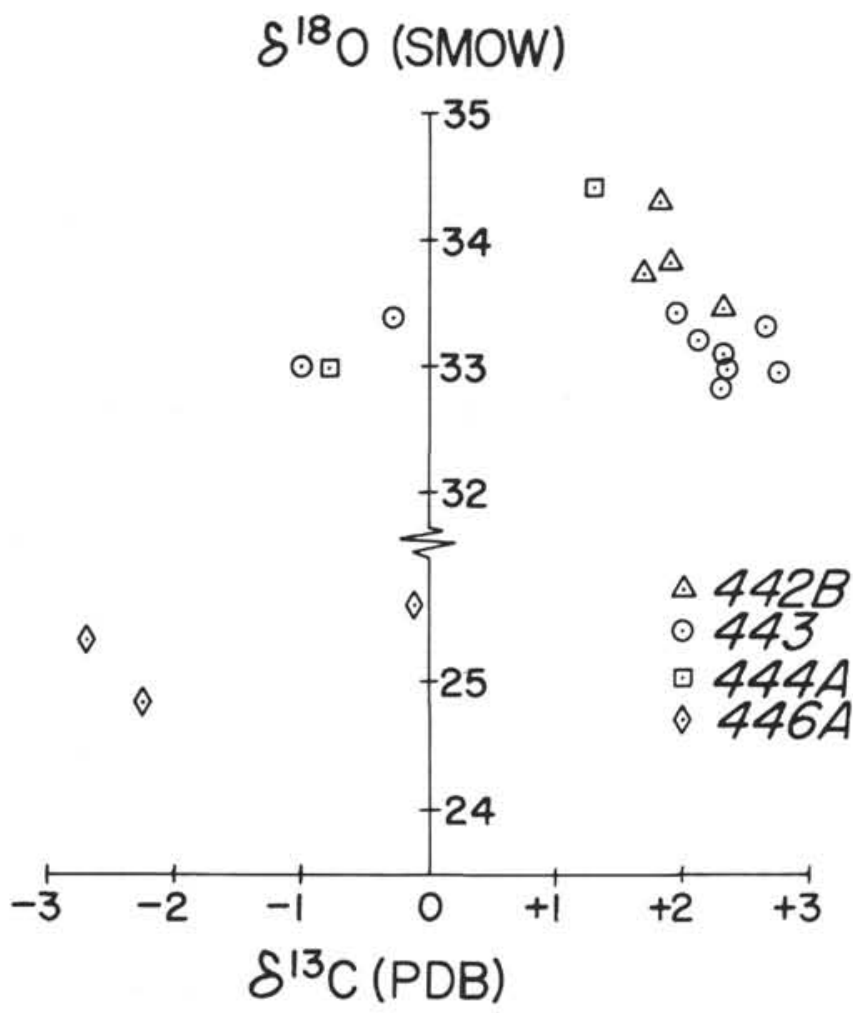

Figure 1. Isotopic composition of vein carbonates from Leg 58 basalts. (Note the break in the $\delta^{18} \mathrm{O}$ axis.)

tive to equilibrium with oceanic bicarbonate. Because the only important source of ${ }^{13} \mathrm{C}$-depleted carbon in the upper part of the ocean crust is sedimentary organic matter, the ${ }^{13} \mathrm{C}$-depleted secondary carbonates in basalts must have precipitated from sea water which migrated through a reasonable thickness of sediment where active oxidation of organic matter was occurring, prior to infiltrating the basalt (Anderson and Lawrence, 1976; Lawrence et al., 1979). Most of the calcite veins therefore would have formed either prior to the onset of oxidation of organic matter in the sediments or after its cessation and the subsequent (upward) diffusive transport in the sediment pore waters of dissolved carbonate species of biogenic origin. Three veins having negative $\delta^{13} \mathrm{C}$ values (Table 2; Figure 1) either formed during active oxidation in the overlying sediments or reflect unusually high contributions from local sources of sedimentary carbon. The vein of Sample 444A-20-2, 131-133 cm, appears to be a good example of the latter case. The sill in which this sample occurs is underlain by 21 meters of mudstone with a particularly high organic-carbon content.

\section{Hole 446A}

The three vein carbonates we analyzed from this hole were substantially depleted in ${ }^{18} \mathrm{O}$, and to a lesser extent in ${ }^{13} \mathrm{C}$, relative to the vein carbonates in other Leg 58 basalts. The oxygen-isotope composition of quartz and smectite in veins from Hole 446A is also depleted somewhat relative to equilibrium with cold sea water (Table 3 ). The general petrographies of the vein minerals and adjacent host rock were not unusual compared to the veins from other holes. The sediments (claystones) into which the basaltic sills were intruded are more abundant in the basement complex at Hole $446 \mathrm{~A}$ than at the other holes. However, this observation gives no significant clue to the origin of the unusual isotopic compositions in the veins from Hole 446A.

There are two alternative interpretations of the data from Hole 446A. The first involves formation of the vein minerals in an "open" basalt-sea water system (i.e., in the presence of isotopically unaltered sea water) at different temperatures. Accordingly, the vein calcite and quartz were precipitated at temperatures between 30 and $50^{\circ} \mathrm{C}$, possibly from different fluids at different times (Table 3). The vein smectite has about the same isotopic composition as the assumed end-member of the basalt-smectite mixing model of Muehlenbachs and Clayton (1972) and can therefore be interpreted as the product of "normal" sea-floor alteration.

We propose a different interpretation for the origin of the secondary minerals in Hole 446A which is based on a "closed-system" alteration of the pore fluids from which the secondary minerals were formed. This model avoids the necessity of invoking a special thermal regime for Hole 446A (for which there appears to be no independent justification) and is capable of explaining some

TABLE 3

Oxygen-Isotope Data on Vein Minerals from Basalts in Hole 446A (carbonates, this study; quartz and smectite, Houghton and Muehlenbachs, this volume)

\begin{tabular}{clccc}
\hline $\begin{array}{c}\text { Sample } \\
\text { (interval in cm) }\end{array}$ & Mineral & $\delta 18 \mathrm{O}$ (SMOW) & $\begin{array}{c}\text { Isotopic Temperature } \\
(\delta 18 \mathrm{O}-0.1) \\
\left({ }^{\circ} \mathrm{C}\right)\end{array}$ & $\begin{array}{c}\delta 18 \mathrm{O} \text { of Water in Equilibrium } \\
\text { with Solid at } 2^{\circ} \mathrm{C}\end{array}$ \\
\hline $446 \mathrm{~A}-1,66-72$ & Calcite & 25.6 & $37^{\mathrm{a}}$ & $-8.0^{\mathrm{a}}$ \\
$4-1,66-72$ & Quartz & 30.7 & $29 \mathrm{~b}^{\mathrm{b}} 43^{\mathrm{c}}$ & $-7.4^{\mathrm{b}}$ to $-11.0^{\mathrm{c}}$ \\
$4-1,79-84$ & Quartz & 29.3 & $35^{\mathrm{b}}$ to $50^{\mathrm{c}}$ & $-8.7^{\mathrm{b}}$ to $-12.3^{\mathrm{c}}$ \\
$13-1,80-84$ & Calcite & 24.9 & $41^{\mathrm{a}}$ & $-8.7^{\mathrm{a}}$ \\
$13-1,80-84$ & Calcite & 25.4 & $39^{\mathrm{a}}$ & $-8.2^{\mathrm{a}}$ \\
$19-4,5-10$ & Smectite & 27.5 & $16^{\mathrm{d}}$ & $-3.4^{\mathrm{d}}$ \\
\hline
\end{tabular}

a Calcite-water fractionation from O'Neil et al., 1969.

bQuartz-water fractionation from Kawabe, 1978.

cQ Quartz-water fractionation from Clayton et al., 1972.

dSmectite-water fractionation from Yeh and Savin, 1977. 
of the isotopic and chemical features in the hole not previously considered.

As discussed previously, interaction with basaltic basement rocks and (or) basal volcanogenic sediments in closed systems is the probable mechanism accounting for the negative $\delta^{18} \mathrm{O}$ gradients observed in pore waters from several DSDP cores (e.g., Lawrence et al., 1975; Gieskes et al., 1978; Lawrence et al., 1979). All the cores analyzed to date which show a negative $\delta^{18} \mathrm{O}$ gradient in the pore fluids also show a negative $\left[\mathrm{Mg}^{++}\right]$gradient and a positive $\left[\mathrm{Ca}^{++}\right]$gradient. These isotopic and chemical shifts are roughly correlated (see Gieskes et al., 1978 ) and are almost certainly the result of related diagenetic transformations (Lawrence et al., 1979; Anderson et al., 1976). Large gradients in $\left[\mathrm{Mg}^{++}\right]$and $\left[\mathrm{Ca}^{++}\right]$in pore waters from Hole $446 \mathrm{~A}$ extend continuously from the sediments overlying the basalt basement sills through the sediments between the sills near the bottom of the hole (Site 446 report). These cation gradients are strong evidence for large-scale closedsystem alteration and the existence of a comparable $\delta^{18} \mathrm{O}$ gradient. The only core whose pore fluids have been analyzed both chemically and isotopically and which has $\left[\mathrm{Mg}^{++}\right]$and $\left[\mathrm{Ca}^{++}\right]$shifts comparable to the values obtained from the inter-sill sediments from Hole $446 \mathrm{~A}$ is Hole 348 from the Norwegian Sea (Gieskes et al., 1978). The maximum shift in the oxygen-isotope composition of pore water from Hole 348 is -8.3 per mill. From a comparison of the maximum cation shifts in Holes 348 and 446A, the present oxygen-isotope composition of pore fluids in the sill-sediment complex in Hole $446 \mathrm{~A}$ is $-9 \pm 1$ per mill. Water in this range of isotopic composition is in equilibrium with the vein quartz and calcite at low temperatures (Table 3 ). (In addition, the vein carbonates from Site 348 are strongly depleted in both ${ }^{13} \mathrm{C}$ and ${ }^{18} \mathrm{O}$ [J. R. Lawrence, pers. comm.], some to a greater extent than the vein carbonates from Hole 446A.) We propose, therefore, that the calcite and quartz are late alteration products, formed well after the development of alteration systems with relatively small water/rock ratios. The oxygenisotope composition of the vein smectite (Table 3) represents an early phase of mineralization (Bass, 1976), prior to extensive isotopic alteration of the pore fluids.

We suggest that the isotopic composition of marine pore fluids becomes progressively altered by "aging" in the basalt-sediment complex. The process of isotopic "aging" involves alteration of basalts and the incorporation of dissolved carbonate species of organic origin; the longer the residence time of the pore fluid in the volcanic-sedimentary assemblage (i.e., the slower the rate of circulation) the more its isotopic composition is shifted (in a negative direction) from normal marine values. The isotopic composition of the calcite (and quartz) veins represents an extreme example (but not necessarily the ultimate end-member) of pore-fluid diagenesis of this type.

We examined some of the important results and interpretations of oxygen-isotope effects in basalt-sea water interactions. For example, Muehlenbachs and Clayton (1972) have proposed a model in which altered basalts are considered to be a simple mixture of almost anhydrous basalt and ${ }^{18} \mathrm{O}$-rich secondary minerals. Muehlenbachs and Clayton (1972) assumed as the lowtemperature end-member a smectite with $\delta^{18} \mathrm{O}$ of 27 per mill and an $\mathrm{H}_{2} \mathrm{O}+$ content of 10 per cent by weight. The mixing line from unaltered basalts to this coordinate is in good agreement with the variation of $\delta 1^{18} \mathrm{O}$ and $\mathrm{H}_{2} \mathrm{O}+$ content in most altered basalt. However, our examination of the literature suggests that the assumed $\delta$-value is probably a minimum for smectite in equilibrium with bottom waters (Yeh, 1974; Yeh and Savin, 1977), and that the assumed $\mathrm{H}_{2} \mathrm{O}+$ content is too high (Grim, 1968; Weaver and Pollard, 1973). To maintain the position of the mixing line, one must assume either that most of the alteration occurred at temperatures somewhat higher than those at the sea floor, or that other low-temperature phases more hydrous than smectite, such as zeolites and hydrated oxides, occur in fairly significant proportion in the alteration product. The general interpretation of the oxygen-isotope composition of most secondary minerals is not compatible with the first explanation, but certainly does not exclude it. There are insufficient data on the mineralogy, chemistry, and isotopic composition of the total product of basalt alteration at the sea floor to test the second possibility. Alternatively, the slope of the basalt-smectite mixing line may be steeper than presently assumed, and a large fraction of altered basalts lies to the right of the line. Progressive alteration resulting in the formation of lowtemperature minerals depletes the interacting pore water in ${ }^{18} \mathrm{O}$. The magnitude of this depletion is inversely proportional to the water/rock ratio. Secondary minerals formed during the alteration process thus acquire progressively lower $\delta^{18} \mathrm{O}$ values compared to the composition they would have if formed in normal sea water at the same temperature. Consequently, the isotopic compositions of bulk altered basalt (residual unaltered rock plus secondary phases) will plot as a curve as alteration proceeds (Figure 2). The lower the water/rock ratio, the greater the deviation from the "normal" basalt-smectite line. These concave-downward paths of basalt alteration result in altered basalts which appear to be $\mathrm{H}_{2} \mathrm{O}^{+}-$ rich.

\section{SUMMARY AND CONCLUSIONS}

The oxygen-isotope compositions of vein carbonates and disseminated carbonates in the basalts from Holes $442 \mathrm{~B}, 443$, and $444 \mathrm{~A}$ indicate equilibrium with normal sea water at low temperature. The carbon-isotope compositions of most of the vein samples are also consistent with precipitation from normal sea water; several of the veins reflect minor contributions from isotopically light organic carbon. The isotopic data on these holes are entirely consistent with pervasive circulation of cold sea water in the basalts and large water/rock ratios during alteration.

The three vein carbonates analyzed from the basalts of Hole $446 \mathrm{~A}$ are depleted in ${ }^{13} \mathrm{C}$ and ${ }^{18} \mathrm{O}$ relative to the veins from the other sites. We interpret these data to mean that secondary minerals formed from sea water which became isotopically modified by low-temperature 


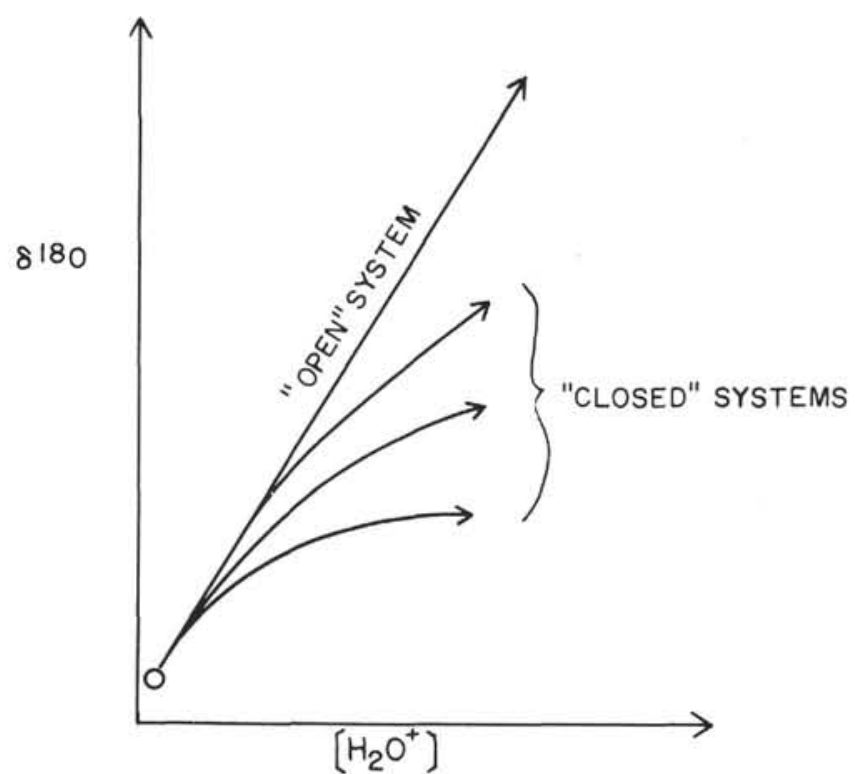

Figure 2. A schematic comparison of low-temperature alteration of basalt in an open system (very high water/rock ratio) and in closed systems. Deviation of the curve of closed-system alteration from the opensystem line increases with decreasing water/rock ratio.

interaction with basalt in closed systems and by the addition of oxidized organic matter. Large gradients in the $\mathrm{Mg}^{++}$and $\mathrm{Ca}^{++}$concentrations in interstitial pore fluids in the sediments above and within the basement complex indicate that large-scale, closed-system alteration of the igneous rocks is now active at Site 446 . We suggest that smectites formed in isotopic equilibrium with bottom water have higher $\delta^{18} \mathrm{O}$ values and lower $\mathrm{H}_{2} \mathrm{O}^{+}$contents than presently assumed in the basaltsmectite mixing model. If the present line is valid for open-system sea-floor alteration, then either the temperature of alteration is higher or other hydrous phases are abundant in the low-temperature/alteration assemblage. Alternatively, the slope of the basalt-smectite mixing line may be steeper than first assumed. As a consequence, a greater number of altered basalts would be ${ }^{18} \mathrm{O}$-poor and $\mathrm{H}_{2} \mathrm{O}^{+}$-rich and could have developed in systems of low water/rock ratios. Hence, the extent of low-temperature-sea-water circulation through the oceanic lithosphere estimated on this basis may be less than currently assumed. More detailed information on the mineralogical, chemical, and isotopic composition of the low-temperature products of interaction within the oceanic crust is urgently needed to evaluate more rigorously the scale and nature of this process.

\section{ACKNOWLEDGMENTS}

I thank Dr. G. deV. Klein for providing the samples. I appreciate the assistance of K. Marsaglia and K. Sherbert in sample preparation and preliminary petrographic examination of the veins. C. Sanderson typed the manuscript, and D. R. Phillips drafted the figures. Drs. J. Hower, R. J. Kirkpatrick, and G. Whitney critically reviewed the manuscript and provided helpful suggestions for improving it. Financial support for this study was provided in part by the National Science Foundation and the U.S. Army Research Office.

\section{REFERENCES}

Anderson, T. F., Donnelly, T. W., Drever, J. I., Eslinger, E., Gieskes, J. M., Kastner, M., Lawrence, J. R., and Perry, E. A., 1976. Geochemistry and diagenesis of deep-sea sediments from Leg 35 of the Deep Sea Drilling Project. Nature, 261, 473-476.

Anderson, T. F., and Lawrence, J. R., 1976. Stable isotope investigations of sediments, basalts, and authigenic phases from Leg 35 cores. In Hollister, C. D., Craddock, C., et al., Init. Repts. DSDP, 35: Washington (U.S. Govt. Printing Office), pp. 497-505.

Bass, M. N., 1976. Secondary minerals in oceanic basalt, with special reference to Leg 34, Deep Sea Drilling Project. In Yeats, R. S., Hart, S. R., et al., Init. Repts. DSDP, 34: Washington (U.S. Govt. Printing Office), pp. 393-432.

Brenneke, J. C., 1977. A comparison of the stable oxygen and carbon isotope composition of Early Cretaceous and Late Jurassic carbonates from DSDP Sites 105 and 367. In Lancelot, Y., Siebold, E., et al., Init. Repts. DSDP, 41: Washington (U.S. Govt. Printing Office), pp. 937-955.

Clayton, R. N., O'Neil, J. R., and Mayeda, T. K., 1972. Oxygen isotope exchange between quartz and water. $J$. Geophys. Res., 77, 3057-3067.

Craig, H., 1957. Isotopic standards for carbon and oxygen and correction factors for mass spectrometric analysis of carbon dioxide. Geochim. Cosmochim. Acta, 12, 133-149.

Craig, H., and Gordon, L. I., 1965. Deuterium and oxygen-18 variation in the ocean and the marine atmosphere. In Tongiorgi, E. (Ed.), Spoleto Conference on Stable Isotopes in Oceanographic Studies and Paleotemperatures, pp. 1-122.

Emrich, K., Ehhalt, D. H., and Vogel, J. C., 1970. Carbon isotope fractionation during the precipitation of calcium carbonate. Earth Planet. Sci. Lett., 8, 363-371.

Gieskes, J. M., Lawrence, J. R., and Galinsky, G., 1978. Interstitial water chemistry, Leg 38. In Talwani, M., Udintsev, G., et al., Init. Repts. DSDP, Supplement to Vols. 38, 39, 40, 41: Washington (U.S. Govt. Printing Office), pp. 121-133.

Gonfiantini, R., 1978. Standards for stable isotope measurements in natural compounds. Nature, 271, 534-536.

Grim, R. E., 1968. Clay Mineralogy (2nd edition): New York (McGraw-Hill).

Kawabe, I., 1978. Calculation of oxygen isotope fractionation in quartz-water system with special reference to the low temperature fractionation. Geochim. Cosmochim. Acta, 42, 613-621.

Klein, G. deV., Kobayashi, K., Chamely, H., Curtis, D. M., Dick, H. J. B., Echols, D. J., Fountain, D. M., Kinoshita, H., Marsh, N. G., Mizuno, A., Nisterenko, G. V., Okada, H., Sloan, J. R., Waples, D. M., and White, S. M., 1978. Off-ridge volcanism and seafloor spreading in the Shikoku Basin. Nature, 273, 746-748.

Kroopnick, P., 1974. The dissolved $\mathrm{O}_{2}-\mathrm{CO}_{2}{ }^{-13} \mathrm{C}$ system in the Eastern Equatorial Pacific. Deep-Sea Res.., 21, 211-227.

Lawrence, J. R., Gieskes, J. M., and Broecker, W. S., 1975. Oxygen isotope and cation composition of DSDP pore waters and the alteration of layer II basalts. Earth. Planet. Sci. Lett., 27, 1-10.

Lawrence, J. R., Drever, J. I., and Kastner, M., 1977. Low temperature alteration of the basalts at Site 395 of the Deep Sea Drilling Project. In Paquet, H., and Tardy, Y. (Eds), Proceedings of the Second International Symposium on Water-Rock Interaction. Section 1. Low-Temperature Water-Rock Interaction. 
Lawrence, J. R., Drever, J. I., Anderson, T. F., and Brueckner, H. K., 1979. Importance of alteration of volcanic material in the sediments of Deep Sea Drilling Site 323: chemistry, ${ }^{18} \mathrm{O} /{ }^{16} \mathrm{O}$ and ${ }^{87} \mathrm{Sr} /{ }^{86} \mathrm{Sr}$. Geochim. Cosmochim. Acta, 43, 573-588.

McCrea, J. M., 1950. On the isotopic chemistry of carbonates and a paleotemperature scale. J. Chem. Phys., 18, 849857.

Muehlenbachs, K., and Clayton, R. N., 1972. Oxygen isotope studies of fresh and weathered submarine basalts. Can. J. Earth Sci., 9, 172-184.

O'Neil, J. R., Clayton, R. N., and Mayeda, T. K., 1969. Oxygen isotope fractionation in divalent metal carbonates. $J$. Chem. Phys., 51, 5547-5558.

Seyfried, W. E., Shanks, W. C., and Bischoff, J. L., 1976. Alteration and vein formation in Site 321 basalts. In Yeats, R.
S., Hart, S. R., et al., Init. Repts. DSDP, 34: Washington (U.S. Govt. Printing Office), pp. 385-392.

Shackleton, N. J., 1967. Oxygen isotope analyses and Pleistocene temperatures reassessed. Nature, 215, 15-17.

Sharma, T., and Clayton, R. N., 1965. Measurement of $\mathrm{O}^{18}$ / $\mathrm{O}^{16}$ ratios of total oxygen from carbonates. Geochim. Cosmochim. Acta, 29, 1347-1353.

Weaver, C. E., and Pollard, L. D., 1973. The Chemistry of Clay Minerals. Developments in Sedimentology, 15: New York (Elsevier).

Yeh, H. W., 1974. Oxygen isotope studies of ocean sediments during sedimentation and burial diagenesis. Ph.D. thesis, Case Western Reserve University.

Yeh, H. W., and Savin, S. M., 1977. Mechanism of burial metamorphism of argillaceous sediments: 3. O-isotope evidence. Geol. Soc. Am. Bull., 88, 1321-1330. 